\title{
Effect of phosphorous, rhizobium inoculation and residue types on chickpea productivity
}

\author{
Wazir Rehan ${ }^{1}$, Amanullah Jan ${ }^{2}$, Waqas Liaqat ${ }^{2}$, Muhammad Faheem \\ Jan $^{2 *}$, Muhammad Dawood Ahmadzai ${ }^{2}$, Haseeb Ahmad ${ }^{2}$, Junaid \\ Haroon $^{2}$, Muhammad Mehran Anjum ${ }^{2}$ and Nawab Ali ${ }^{2}$ \\ 1. Agricultural Research Institute Tarnab, Peshawar-Pakistan \\ 2. Department of Agronomy, The University of Agriculture Peshawar-Pakistan \\ *Corresponding author's email: faheemjan.uap@gmail.com
}

Citation

Wazir Rehan, Amanullah Jan, Waqas Liaqat, Muhammad Faheem Jan, Muhammad Dawood Ahmadzai, Haseeb Ahmad, Junaid Haroon, Muhammad Mehran Anjum and Nawab Ali. Effect of phosphorous, rhizobium inoculation and residue types on chickpea productivity. Pure and Applied Biology. Vol. 7, Issue 4, pp1203-1213. http://dx.doi.org/10.19045/bspab.2018.700140

\begin{tabular}{llll}
\hline \hline Received: 14/05/2018 & Revised: 17/08/2018 & Accepted: 20/08/2018 & Online First: 30/08/2018 \\
\hline
\end{tabular}

\section{Abstract}

An experiment with the objective to evaluate the effect of phosphorous, rhizobium inoculation and residue types on chickpea productivity was conducted during Rabi 2014-15 at Agronomy Research Farm of The University of Agriculture Peshawar. Randomized complete block design (RCBD) was used for the experiment with four replications. Inoculated and un-inoculated seeds were sown with three phosphorus (P) levels (30, 60, and $90 \mathrm{~kg} \mathrm{ha}^{-1}$ ) and three residue types (cereal, legume and oilseed). A control treatment was also included. Plots supplied with $90 \mathrm{~kg} \mathrm{P} \mathrm{ha}^{-1}$ induced early flowering and maturity with higher nodules plant ${ }^{-1}$, plant height, number of pods plant ${ }^{-1}$ and biological yield which was statistically similar with application of $60 \mathrm{~kg} \mathrm{P} \mathrm{ha}^{-1}$. Significantly higher number of grains pod $^{-1}$, thousand grains weight and grain yield was recorded in plots treated with phosphorous at @ $60 \mathrm{~kg} \mathrm{ha}^{-1}$. Residue types showed non-significant effect on all studied parameters. Seeds treated with rhizobium produced maximum nodules plant ${ }^{-1}$, grains pod $^{-1}$, pods plant $^{-1}, 1000$-grains weight, biological yield and grain yield. The interaction between phosphorus and rhizobium inoculation exposed that seeds treated with rhizobium resulted in maximum biological and grain yield when fertilized with $60 \mathrm{~kg} \mathrm{P} \mathrm{ha}^{-1}$. It can be concluded that chickpea when inoculated with rhizobium and fertilized with $60 \mathrm{~kg} \mathrm{ha}^{-1}$ phosphorus resulted in maximum yield and yield attributes of chickpea.

Keywords: Cereal; Grain yield; Legume; Nodules plant ${ }^{-1}$; Plant height; Pods plant $^{-1}$

\section{Introduction}

Chickpea (Cicer arietinum L.) belongs to family Fabaceae and is grown in many parts of the world with a total production of 9.8 million tons from an area of 11.1 million hectares [1]. Pulses are important crops having high amount of protein in its seed and contribute considerably to dietary protein [2]. Chickpea not only plays an important role in human diet but also improves soil fertility by fixing atmospheric nitrogen [3]. Therefore, pulses have become a key target for 
agricultural, environmental and biotechnological research. Among pulses, chickpea is one of the major pulse crop of our country grown on an area under arid and semi-arid conditions. Despite the high yield potential over $4000 \mathrm{~kg} \mathrm{ha}^{-1}$ of chickpea [4] the actual yield is still significantly lower in Pakistan. Minimum yield of chickpea is due to combination of biotic and abiotic stresses [5]. In Pakistan during 2014-15 it was cultivated on 0.960 million hectares with total production of 0.484 million tons having an average yield of $504 \mathrm{~kg} \mathrm{ha}^{-1}$ [6].

Phosphorus (P) is an essential nutrient of numerous vital plant structural compounds. It acts as a catalyst in several biochemical reactions occurred in plants. It plays an important role in capturing and converting the solar energy into useful plant compounds. These compounds help in the general health and vigor of plants [7]. Phosphorus is connected with some particular plant growth factors that are: root development, vigorous stem, enhanced flower formation and seed production, earlier and more uniform crop maturity, increase nitrogen fixing capacity of legumes, improvement in crop quality and resistance to plant diseases [8, 9]. It is required for higher and sustainable production of grain legumes. Generally, legumes have higher $\mathrm{P}$ requisites due to more consumption of energy in the process of symbiotic nitrogen fixation [10]. Low soil $\mathrm{P}$ and poor consumption efficiency of $\mathrm{P}$ hinders the productivity of most grain legumes [11, 12]. Gupta et al. [13] and Redy et al. [14] reported that $\mathrm{P}$ application significantly enhanced the yield in red chickpea. P plays an important role in pod filling and finally improves the grain yield of chickpea.

Soil lacking native rhizobia of chickpea requires artificial seed inoculation for improving root nodulation and yield of the crop [15]. Artificial rhizobium inoculation of chickpea reacts positively when grown in soils that contain its native rhizobia [16].
Application of biofertilizers such as rhizobium can decrease the need for chemical fertilizers and reduce its adverse effects on environment. In the improvement of sustainable agricultural techniques, biofertilizers have a great importance in decreasing environmental pollution and deterioration of nature [17]. Residues are important component for the stability of agricultural ecosystems. Areas where regular mechanical harvesting is practiced, most of the residues are left in the field and can be recycled for nutrients supply. Leaving residues in the field after harvest is one of the way to stabilize soil fertility. As residues are good sources of plant nutrients, both farmers and researchers have shown more curiosity in management of residue types. Usually, it acts as valuable management tool because of high costs of inorganic fertilizers and less yield in monoculture cropping systems [18]. Research studies have revealed that residues enhanced soil fertility, crop productivity, reduced wind and water erosion and prevented nutrients leaching and losses by run-off [19]. Keeping in view the importance of seed inoculation with rhizobium, phosphorus and residues, the present experiment was designed to determine the impact of phosphorous and residues on chickpea inoculated with rhizobium.

\section{Materials and methods}

To study the impact of rhizobium inoculation with different phosphorus levels and residue types on chickpea productivity, an experiment was conducted at Agronomy Research Farm of The University of Agriculture, Peshawar during Rabi 2014-15. Experiment comprised of three factors i.e. residue types (cereal, legume, oilseed), rhizobium inoculation (inoculated and uninoculated) and phosphorous levels (30, 60 and $90 \mathrm{~kg} \mathrm{ha}^{-1}$ ). A control treatment was also included for comparison. The experiment was arranged in randomized complete block design having four replications. A sub plot 
size of $3 \mathrm{~m} \mathrm{x} 1.5 \mathrm{~m}$ was used. Each plot consisted of 5 rows with $30 \mathrm{~cm}$ row to row distance. Nitrogen was applied during sowing at the rate of $25 \mathrm{~kg} \mathrm{ha}^{-1}$ as basal dose. Rhizobium inoculum "BIOZOTE" was used for seed inoculation. Prior to seed sowing, the chickpea seeds were first sprinkled with sugar syrup and then inoculum was mixed with seed in shady place. The seed was kept for 20 minutes and then it was sown. Chickpea variety NIFA-2005 was sown at the rate of $60 \mathrm{~kg} \mathrm{ha}^{-1}$ with single row hand drill. Residue types each at the rate of 5 tons $\mathrm{ha}^{-1}$ were incorporated. Other agronomic practices were carried out uniformly for all the experimental units throughout the growing season. Data was recorded for days to first flowering, days to maturity, plant height, nodules plant $^{-1}$, number of pods plants $^{-1}$, numbers of seeds pod ${ }^{-1}, 1000$-grain weight, grain yield and biological yield.

\section{Procedure for recording data}

Number of days to flowering was recorded by counting the total number of days from the date of sowing to date till appearance of first flower. Days to maturity were recorded as the total number of days from the date of planting to day when $90 \%$ plants in each subplot turned brown and ready for harvest. Data on plant height $(\mathrm{cm})$ was recorded by measuring height of ten randomly selected plants in each subplot with the help of meter rod and averaged. Data on nodules plant ${ }^{-1}$ were recorded at flowering stage by counting the number of nodules in five random plants selected in each subplot. For recording nodules plant ${ }^{-1}$, the spot was irrigated first and when it reached to watter (field capacity), the sampled plants were uprooted with the help of spade and nodules were counted and averaged. Number of pods plant ${ }^{-1}$ was counted on ten randomly selected plants in each subplot after harvesting. Ten random pods in each subplot were selected, grains in these pods were counted and averaged for determining number of grains pod $^{-1}$. A random sample of thousand seeds were counted from each treatment and weighed on sensitive electronic balance to record 1000 grains weight in grams. For biological yield three central rows in each subplot were harvested, sun dried, weighed and converted into $\mathrm{kg} \mathrm{ha}^{-1}$. Grain yield was recorded by threshing three central rows harvested for biological yield in each subplot. The threshed seeds were cleaned and weighed to determine grain yield $\left(\mathrm{kg} \mathrm{ha}^{-1}\right)$.

\section{Statistical analysis of the data}

The collected data was analyzed statistically according to analysis of variance procedure as appropriate for randomized complete block design. Means were compared using least significant difference (LSD) test at $\mathrm{P} \leq 0.05$ upon significant F-test [20].

\section{Results and discussion}

\section{Days to flowering}

Data concerning days to first flowering (Table 1) reflects that phosphorus (P) levels had significantly influenced days to flowering in chickpea. Effect of rhizobium inoculation and residues types with all possible interactions were found nonsignificant for days to flowering. Mean data indicated that increasing $\mathrm{P}$ rate decreased days to flowering with minimum days to flowering was observed in plots treated with higher rate of $\mathrm{P}\left(90 \mathrm{~kg} \mathrm{ha}^{-1}\right)$. Control plots showed delayed flowering than rest. In control plots delayed flowering initiation was observed due to prolonged growth period against the treated plots. Our results are supported by the findings of Neenu et al. [21] and Saedullah [22] who reported that flowering was delayed in control plots as compared to phosphorus fertilized plots.

\section{Days to maturity}

Days to maturity was significantly affected by phosphorous while rhizobium inoculation and residues types had a non-significant effect on days to maturity of chickpea (Table 1). Mean data indicated that increasing $P$ rate decreased days to maturity in chickpea with 
less days to maturity recorded for $90 \mathrm{~kg} \mathrm{P}^{\mathrm{P}} \mathrm{ha}^{-}$ 1. An inverse relation was found between $P$ and days to maturity in chickpea. Neenu et al. [21] indicated that phosphorus deficiency delays maturity as compared to phosphorus fertilized plots in chickpea crop.

\section{Plant height (cm)}

Phosphorous had a significant while rhizobium inoculation and residues types had a non-significant effect on plant height of chickpea (Table 1). Control vs rest comparison was found significant for plant height of chickpea while all interactions were found non-significant. Mean values showed that taller plants were recorded for highest level of P (90 kg ha-1) which was statistically similar with $60 \mathrm{~kg} \mathrm{ha}^{-1} \mathrm{P}$ while shortest plants were recorded for $30 \mathrm{~kg} \mathrm{ha}^{-1} \mathrm{P}$ application. Our findings are in accordance with those of Ahmad et al. [23] and Dutta and Bandyopadhyay [24] who reported significant effects of $\mathrm{P}$ on plant height of chickpea. Also numerous other studies reported enhanced morphological growth due to direct application of phosphorus [25-27]. Rudresh [28] reported similar results by concluding that plant height was not affected significantly with rhizobium inoculation.

\section{Nodules plant ${ }^{-1}$}

Data showing nodules plant ${ }^{-1}$ are given in (Table 1). Mean data indicated that number of nodules plant ${ }^{-1}$ were significantly affected by $\mathrm{P}$ and rhizobium inoculation while residue types had no significant effect on nodules plant $^{-1}$. Nodules numbers increased with increasing $\mathrm{P}$ rate with more nodules plant $^{-1}$ counted for highest rate of $P$ i.e. $90 \mathrm{~kg} \mathrm{ha}^{-1}$. Seeds inoculated with rhizobium showed higher number of nodules plant ${ }^{-1}$ than noninoculated seeds. All possible interactions were found non-significant. Control plots showed less number of nodules plant ${ }^{-1}$ than rest. The higher number of nodules plant ${ }^{-1}$ might be associated with enhanced root proliferation due to phosphorus application. More nodules plant ${ }^{-1}$ with rhizobium inoculation might be due to the reason that inoculation promote rhizobial activities in soil and in turn nodules number. Similar results were reported by [29] who reported that rhizobium inoculation in chickpea increases $27 \%$ of nodules plant ${ }^{-1}$ as compared to control plots. These results are in line with the findings of other scientists $[30,31]$ who found that number of nodules per plant was the highest in plants inoculated with rhizobium.

\section{Number of pods plant ${ }^{-1}$}

Number of pods plant ${ }^{-1}$ is an important yield determinant in pulse crops. Data concerning number of pods plant ${ }^{-1}$ is given in Table 1 . Data exhibited that number of pods plant $^{-1}$ significantly increased with $\mathrm{P}$ and rhizobium inoculation while residues types and all interactions did not cause any significant variation in number of pods plant ${ }^{-1}$. Control compared with treated plots was also significant. With increase in $\mathrm{P}$ remarkable increase in pods plant $^{-1}$ was found. Plots treated with $30 \mathrm{~kg} \mathrm{P} \mathrm{ha}{ }^{-1}$ produced lowest pods plant ${ }^{-1}$ while highest pods plant ${ }^{-1}$ was recorded in plots having $90 \mathrm{~kg} \mathrm{P} \mathrm{ha}^{-1}$. Seeds inoculated with rhizobium produced plants with more pods compared to un-inoculated seeds. Increase in the number of pods plant ${ }^{-1}$ with the application of $\mathrm{P}$ might have resulted from more growth of the plant which in turn had increased number of pods plant ${ }^{-1}$. These results are supported by the findings of [32] who reported that application of $\mathrm{P}$ at higher levels resulted in increased crop growth particularly positive impact was noted on branching, pods, seeds pod ${ }^{-1}$, seed index and seed yield. The number of pods and seed index was improved under higher $P$ application [33]. Similarly inoculated seeds have more pods plant ${ }^{-1}$ and these results are supported by the findings of [17] who reported that number of pods plant $^{-1}$ significantly increased with rhizobium inoculation. These results are also in resemblance with those of [34] who 
determined that inoculation positively increased number of pods plant ${ }^{-1}$ in chickpea. The minimum number of pods in the control might have been due to less availability of $\mathrm{P}$ and stunted growth.

Table 1. Days to flowering, days to maturity, plant height $(\mathrm{cm})$, nodules plant $^{-1}$ and number of pods plant ${ }^{-1}$ of chickpea as affected by crop residue types, rhizobium inoculation and phosphorous levels.

\begin{tabular}{|c|c|c|c|c|c|}
\hline Residue types (RT) & $\begin{array}{c}\text { Days to } \\
\text { flowering }\end{array}$ & $\begin{array}{l}\text { Days to } \\
\text { maturity }\end{array}$ & $\begin{array}{l}\text { Plant height } \\
\text { (cm) }\end{array}$ & $\begin{array}{c}\text { Nodules } \\
\text { plant }^{-1}\end{array}$ & $\begin{array}{l}\text { Number of } \\
\text { pods plant }^{-1}\end{array}$ \\
\hline Cereal & 139 & 189 & 81.2 & 71 & 46 \\
\hline Legume & 139 & 189 & 81 & 72 & 49 \\
\hline Oilseed & 139 & 189 & 81.9 & 70 & 49 \\
\hline $\operatorname{LSD}_{(0.05)}$ & NS & NS & NS & NS & NS \\
\hline \multicolumn{6}{|c|}{ Rhizobium inoculation (I) } \\
\hline Inoculated & 139 & 189 & 82.2 & $75 \mathrm{a}$ & $49 \mathrm{a}$ \\
\hline Un-inoculated & 139 & 190 & 80.5 & $67 \mathrm{~b}$ & $47 \mathrm{~b}$ \\
\hline $\operatorname{LSD}_{(0.05)}$ & NS & NS & NS & 4.5 & 1.5 \\
\hline \multicolumn{6}{|c|}{ Phosphorous (P) levels (kg ha-1) } \\
\hline 30 & $140 \mathrm{a}$ & $190 \mathrm{a}$ & $79.6 \mathrm{~b}$ & $66 \mathrm{~b}$ & $46 \mathrm{~b}$ \\
\hline 60 & $139 \mathrm{ab}$ & $189 \mathrm{ab}$ & $81.9 \mathrm{ab}$ & $73 \mathrm{ab}$ & $49 \mathrm{ab}$ \\
\hline 90 & $138 \mathrm{~b}$ & $188 \mathrm{~b}$ & $82.6 \mathrm{a}$ & $74 \mathrm{a}$ & $50 \mathrm{a}$ \\
\hline $\operatorname{LSD}_{(0.05)}$ & 1 & 1 & 2.26 & 5 & 3 \\
\hline Control vs rest & $* *$ & $*$ & $*$ & $*$ & $* *$ \\
\hline Control & $142 \mathrm{a}$ & $191 \mathrm{a}$ & $76.5 \mathrm{~b}$ & $59 \mathrm{~b}$ & $39 \mathrm{~b}$ \\
\hline Rest & $139 \mathrm{~b}$ & $189 \mathrm{~b}$ & $81.4 \mathrm{a}$ & $71 \mathrm{a}$ & $48 \mathrm{a}$ \\
\hline \multicolumn{6}{|l|}{ Interactions } \\
\hline RT x I & NS & NS & NS & NS & NS \\
\hline $\mathrm{RT} \times \mathrm{P}$ & NS & NS & NS & NS & $\mathrm{NS}$ \\
\hline I x P & NS & NS & NS & NS & NS \\
\hline RT x I x P & NS & NS & NS & NS & NS \\
\hline
\end{tabular}

Means of same categories followed by different letters are statistically different at $5 \%$ level of probability. NS = Nonsignificant $*=$ Statistical significance at $5 \%$ level of probability $* *=$ Statistical significance at $1 \%$ level of probability

\section{Number of grains pod $^{-1}$}

Data pertaining to number of grains $\operatorname{pod}^{-1}$ is presented in Table 2. Analysis of data showed that $\mathrm{P}$ and rhizobium inoculation significantly affected grains pod $^{-1}$ while residues types and all possible interactions were found non-significant for numbers of grains $\operatorname{pod}^{-1}$. Mean values for $\mathrm{P}$ indicated that application of 60 and $90 \mathrm{~kg} \mathrm{ha}^{-1} \mathrm{P}$ produced pods with statistically similar and higher number of grains while less grains were recorded for $30 \mathrm{~kg} \mathrm{P} \mathrm{ha}^{-1}$. Seeds inoculated with rhizobium produced significantly more number of grains pod $^{-1}$ as compared with uninoculated seeds. The application of phosphorus might have enhanced the photosynthetic activity which resulted in more number of seeds per plant. Similar findings were declared by [35] who recorded more grains pod ${ }^{-1}$ at $60 \mathrm{~kg} \mathrm{P} \mathrm{ha}^{-1}$ as compared with other P levels. Inoculated plots produced more grains pod ${ }^{-1}$ compared to un-inoculated 
plots. Increase in the number of grains $\operatorname{pod}^{-1}$ was probably due to availability of more $\mathrm{N}$ on account of its uptake by plants due to inoculation. The significant effects of seed inoculation on number of grains pod $^{-1}$ were also noted by [36]. [29] reported that rhizobium inoculation had a positive effect on growth, yield and yield attributes in chickpea.

\section{Thousand grains weight (g)}

Analysis of data indicated that thousand grains weight were significantly affected by $\mathrm{P}$ and rhizobium inoculation (Table 2). Residue types with all possible interactions did not cause significant variations in thousand grains weight of chickpea. Mean values of the data showed that higher thousand grain weight was recorded in plots that received $60 \mathrm{~kg} \mathrm{P} \mathrm{ha}^{-1}$ followed by $90 \mathrm{~kg}$ $\mathrm{P} \mathrm{ha}^{-1}$ with no statistical difference while lower thousand grains weight was recorded in plots treated with $30 \mathrm{~kg} \mathrm{P}$ ha $^{-1}$. Heavy grains were recorded in plots where seeds were inoculated with rhizobium than uninoculated seeds. Increasing $P$ levels increased 1000 grains weight by improving photosynthetic activity and better seed formation. Better growth and development of crop plants due to phosphorus supply and nitrogen uptake might have increased the supply of assimilates to seed, which ultimately gained more weight. Our results are supported by the findings of [37] who reported heavier grains due to $\mathrm{P}$ application. A positive response of seed weight to inoculation of annual legumes was reported by $[17,27,38]$. Nonetheless, phosphorous either alone or in combination with inoculation, resulted in a significantly maximum weight of thousand seeds of chickpea. These results are in agreement with the findings of some other studies [38, 27]. The reason for maximum 1000 seeds weight recorded for $\mathrm{P}$ and inoculation treatment could be due to the enhanced growth and development of plants that resulted from $\mathrm{P}$ supply and its positive effect on nitrogen fixation. The resulting nitrogen availability might have promoted the supply of assimilates to seed thereby enabling them to gain more weight. Better growth and development of plants due to rhizobium inoculation might have influenced the nutrient supply to plant growth which resulted in producing more assimilates. These assimilates might have partitioned more efficiently from source to sink and finally added to more seed weight [29]. Different researchers [39, 40] showed that rhizobium inoculation significantly increased 1000 seed weight of chickpea.

\section{Biological yield $\left(\mathrm{kg} \mathrm{ha}^{-1}\right)$}

Statistical analysis of the data depicted that biological yield was significantly affected by $P$ and rhizobium inoculation (Table 2). Residue types and all other interactions except $\mathrm{P} x$ inoculation was found nonsignificant. Interaction of $\mathrm{P} x \mathrm{I}$ revealed that seeds inoculated with rhizobium when fertilized with $60 \mathrm{~kg} \mathrm{ha} \mathrm{Pa}^{-1} \mathrm{P}$ resulted in maximum biological yield while minimum biological yield was recorded in plots where $30 \mathrm{~kg} \mathrm{ha}^{-1} \mathrm{P}$ was applied to un-inoculated seeds (Figure 1). The positive effect of $\mathrm{P}$ on total biomass was in agreement with earlier studies $[26,41,42]$ as well as the strongest effect by the combined application of inoculation and $\mathrm{P}$ [38]. The substantial increase in biological yield due to $P$ application could be attributed to the increased vegetative growth, possibly a result of its extensive root system under $\mathrm{P}$ fertilization. These results are supported by findings of [43] who stated that rhizobium inoculation increases biological yield in chickpea crop. More plant growth, yield and yield components are the possible reasons for higher biological yield in inoculated plots [38]. Un-inoculated treatments and plots with no phosphorous application showed minimum biological yield.

Grain yield ( $\left.\mathrm{kg} \mathrm{ha}^{-1}\right)$ 
Significant variations in grain yield was indicated by the individual as well as interactive effect of phosphorous and rhizobium inoculation (Table 2 ). The residue types and all other interactive effects were found non-significant. Mean data revealed that plots having rhizobium inoculated seeds and fertilized with $60 \mathrm{~kg} \mathrm{P} \mathrm{ha}{ }^{-1}$ produced maximum grain yield while minimum grain yield was recorded in plots having uninoculated seeds and treated with lower rate of $P$ i.e. $30 \mathrm{~kg} \mathrm{ha}^{-1}$ (Figure 2). Similar effect of $\mathrm{P}$ on grain yield of legumes was found by other researchers $[24,41]$ and attributed to the role of $\mathrm{P}$ in the meristematic activity of plant tissues and in the synthesis of other growth components from carbohydrates [44]. The increase in yield due to the more availability of $\mathrm{P}$ might have increased the plant growth and better seed development which in turn increased grain yield. These results are in resemblance with [37]. Inoculation of chickpea seed significantly improved its grain yield $[45,46]$. The effect was even more pronounced when inoculation and $\mathrm{P}$ were applied in combination resulting in a yield advantage over the control. This might have resulted from the positive effects of $\mathrm{P}$ on the process of nitrogen fixation where the increased supply of nitrogen through inoculation resulted in enhanced plant growth that eventually leads to higher yield. The increase in yield due to inoculation could be attributed to increase in yield components of the crop in inoculated plots. These findings are identical with those of [29] who reported $22 \%$ increase in grain yield by inoculation.

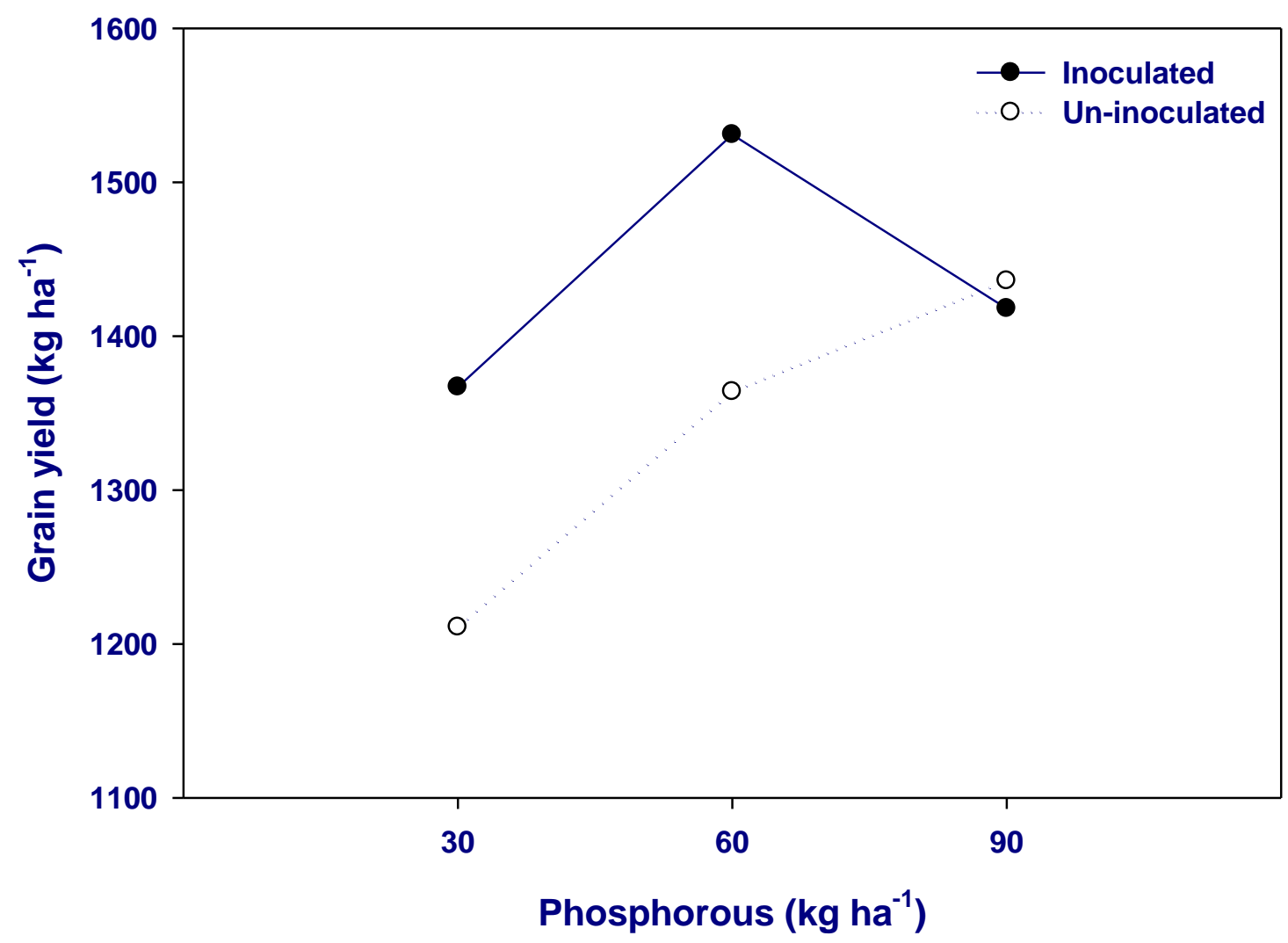

Figure 1. Interaction of phosphorous and rhizobium inoculation for grain yield (kg ha-1) of chickpea 


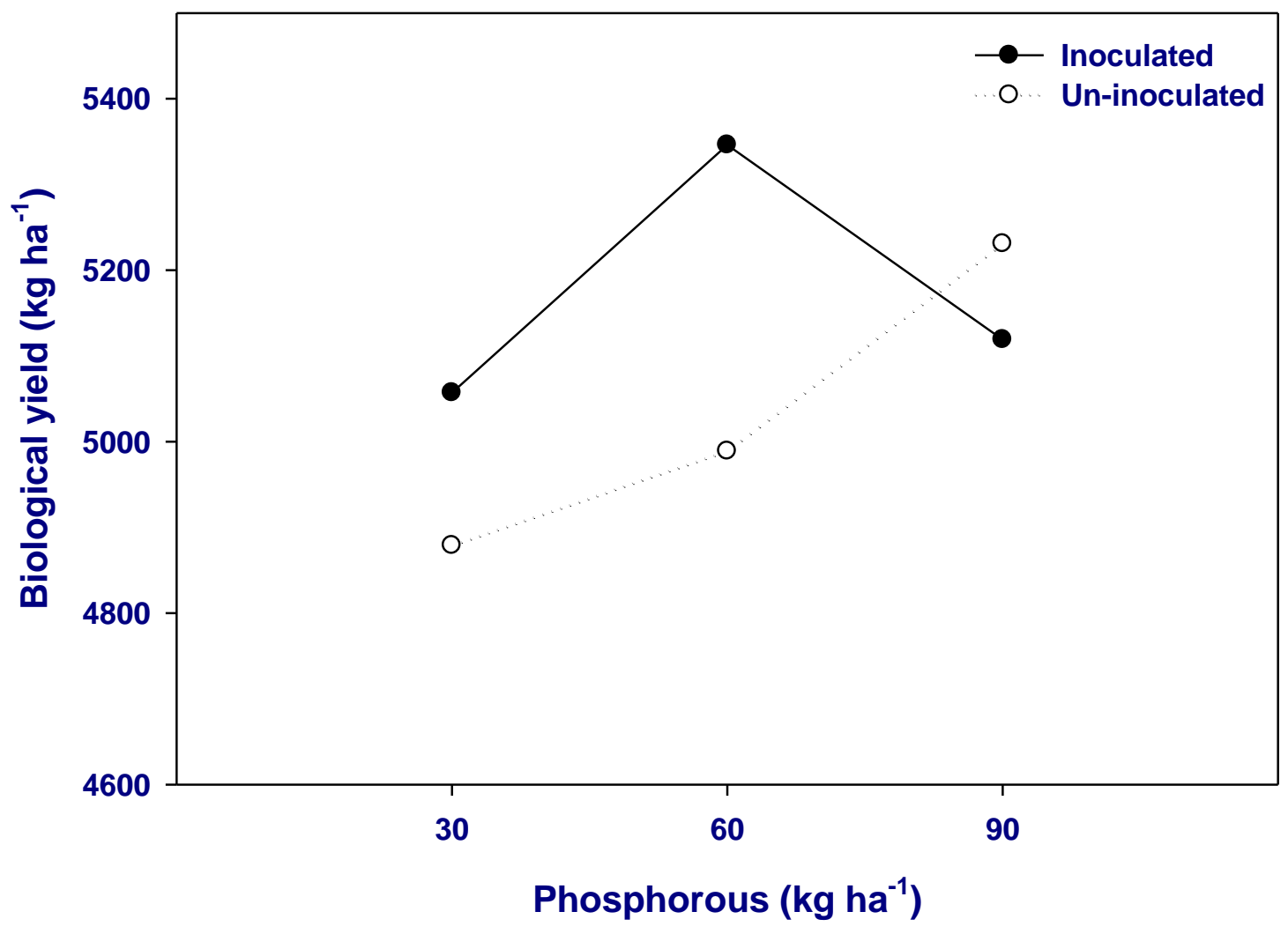

Figure 2. Interaction of phosphorous and rhizobium inoculation for biological yield (kg ha1) of chickpea

Table 2. Number of grains pod ${ }^{-1}$, thousand grains weight (g), biological yield $\left(\mathrm{kg} \mathrm{ha}^{-1}\right)$ and grain yield $\left(\mathrm{kg} \mathrm{ha}^{-1}\right)$ of chickpea as affected by crop residue, rhizobium inoculation and phosphorous levels.

\begin{tabular}{|c|c|c|c|c|}
\hline $\begin{array}{l}\text { Residue types } \\
\text { (RT) }\end{array}$ & $\begin{array}{l}\text { Number of grains } \\
\text { pod }^{-1}\end{array}$ & $\begin{array}{c}\text { Thousand grains } \\
\text { weight (g) }\end{array}$ & $\begin{array}{c}\text { Biological yield } \\
\left(\mathrm{kg} \mathrm{ha}^{-1}\right)\end{array}$ & $\begin{array}{c}\text { Grain yield (kg } \\
\left.\text { ha }^{-1}\right)\end{array}$ \\
\hline Cereal & 1.7 & 244.2 & 5093 & 1374 \\
\hline Legume & 1.7 & 246.1 & 5084 & 1401 \\
\hline Oilseed & 1.6 & 244.3 & 5133 & 1389 \\
\hline $\operatorname{LSD}_{(0.05)}$ & NS & NS & NS & NS \\
\hline \multicolumn{5}{|c|}{ Rhizobium inoculation (I) } \\
\hline Inoculated & $7 \mathrm{a}$ & $247.4 \mathrm{a}$ & $5174 \mathrm{a}$ & $1439 \mathrm{a}$ \\
\hline Un-inoculated & $1.6 \mathrm{~b}$ & $242.3 \mathrm{~b}$ & $5033 \mathrm{~b}$ & $1337 \mathrm{~b}$ \\
\hline $\operatorname{LSD}_{(0.05)}$ & 3 & 3.8 & 114.8 & 76.7 \\
\hline \multicolumn{5}{|c|}{ Phosphorous (P) levels $\left(\mathrm{kg} \mathrm{ha}^{-1}\right)$} \\
\hline 30 & $1.6 \mathrm{~b}$ & $241.6 \mathrm{~b}$ & $4968 \mathrm{~b}$ & $1289 \mathrm{~b}$ \\
\hline 60 & $1.7 \mathrm{a}$ & $248.6 \mathrm{a}$ & $5167 \mathrm{ab}$ & $1447 \mathrm{a}$ \\
\hline 90 & $1.7 \mathrm{ab}$ & $244.5 \mathrm{ab}$ & $5175 \mathrm{a}$ & $1427 \mathrm{ab}$ \\
\hline
\end{tabular}




\begin{tabular}{|c|c|c|c|c|}
\hline LSD $_{(0.05)}$ & 0.05 & 4.92 & 170.56 & 77.64 \\
\hline $\begin{array}{c}\text { Control vs } \\
\text { rest }\end{array}$ & $* *$ & $* *$ & $*$ & $* *$ \\
\hline Control & $1.5 \mathrm{~b}$ & $232.3 \mathrm{~b}$ & $4756 \mathrm{~b}$ & $1101 \mathrm{~b}$ \\
\hline Rest & $1.7 \mathrm{a}$ & $244.9 \mathrm{a}$ & $5103 \mathrm{a}$ & $1388 \mathrm{a}$ \\
\hline Interactions & & & & \\
\hline RT x I & NS & NS & NS & NS \\
\hline RT x P & NS & NS & NS & NS \\
\hline I x P & NS & NS & $*$ & $*$ \\
\hline RT x I x P & NS & NS & NS & NS \\
\hline
\end{tabular}

Means of same categories followed by different letters are statistically different at $5 \%$ level of probability. NS = Nonsignificant $*=$ Statistical significance at $5 \%$ level of probability** $=$ Statistical significance at $1 \%$ level of probability

\section{Conclusion}

It can be concluded from the study that yield and yield components of chickpea were found higher at phosphorus application of 60 $\mathrm{kg} \mathrm{ha}{ }^{-1}$. Rhizobium inoculated seeds performed well in terms of grain yield than un-inoculated seeds. Therefore, application of phosphorus at the rate of $60 \mathrm{~kg} \mathrm{ha}^{-1}$ to seeds inoculated with rhizobium is recommended for higher production of chickpea under the climatic conditions of Peshawar region.

\section{Authors' contributions}

Conceived and designed the experiments: W Rehan \& A Jan, Performed the experiments: W Rehan \& A Jan, Analyzed the data: W Rehan, W Liaqat \& H Ahmad, Contributed materials/ analysis/ tools: MD Ahmadzai, MF Jan, J Haroon, N Ali \& MM Anjum, Wrote the paper: W Liaqat, MF Jan, H Ahmad \& W Rehan.

\section{References}

1. FAO (2009). Food and Agriculture Organization of the United Nations. FAO Production Year Book. Rome, Italy: FAO.

2. Ali M \& Kumar S (2009). Major technology advances in Pulses. J Food Legume 23: 169-185.

3. Kantar F, Hafeez FY, Shivakumar BG, Sundaram SP, Tejera NA, Alsam A, Bano A \& Raja P (2007). Chickpea: Rhizobium management and nitrogen fixation. Chickpea Breed Mgt 179-192.
4. Singh KB (1990). Prospects of developing new genetic material and breeding methodologies for chickpea improvement. In: Saxena MC, Cubero JI, Wery J (eds) Present Status and Future Prospects of Chickpea Crop Production and Improvement in the Mediterranean Countries. Options MéditerranéennesSérie-Séminaries-no 9-CIHEAM, Paris. 43-50.

5. Singh KB (1993). Problems and prospects of stress resistant breeding in chickpea. In Singh KB, Saxena MC (Eds) Breeding for Stress Tolerance in Cool-Season Food Legumes. John Wiley and Sons, Chichester. 17-23.

6. MNSFR (2014-15). Ministry for National Food Security and Research. Economic wing, Islamabad, Pakistan.

7. Griffith B (2010). Efficient Fertilizer Use - Phosphorus, 1-7.

8. Magid J, Tiessen $\mathrm{H}$ \& Condron LM (1996). Dynamics of organic phosphorus under natural and agricultural ecosystems. In: Piccolo, A. (ed.) Humic Substances in Terrestrial Ecosystems. Elsevier Amsterdam 2: 429-466.

9. Cross AF \& Schlesinger WH (1995). A literature review and evaluation of the Hedley fractionation scheme: applications to the biogeochemical cycle of soil phosphorus in natural ecosystems. Geoderma 64: 197-214. 
10. Islam M, Mohsan S, Ali S, Khalid R \& Afzal S (2012). Response of chickpea to various levels of phosphorus and sulphur under rainfed conditions in Pakistan. Romanian Agric Res 29: 175-183.

11. Aulakh MS, Pasricha NS \& Bahl GS (2003). Phosphorus fertilizer response in an irrigated soybean-wheat production system on a subtropical, semiarid soil. Field Crops Res 80: 99-109.

12. Sheikh M \& Siadat M (2003). Effect of supplemental irrigation on yield of chickpea. Master Thesis. Azad Islamic University, Dezfol, Iran.

13. Gupta SC, Sukhlal, Namdeo \& Paliwal KK 1998. Effect of phosphorus levels and microbial inoculants on symbiotic traits, $\mathrm{N}$ and $\mathrm{P}$ uptake, quality and yield of rainfed chickpea. All India Coordinated Project Improvement of Pulse. RAK.

14. Reddy Y, Bheemaiah SG, Shantaram MV \& Raju AS (1993). Phosphorus nutrition of red gram in red sandy loam soil under intercropping condition. Fertilizer News. 38(5): 37-43.

15. Khattak SG, Khan DF, Shah,SH, Madani MS \& Khan T (2006). Role of rhizobial inoculation in the production of chickpea crop. Soil Environ 25: 143-145.

16. Sharma LC, Saxena S, Jain RK, Prasad J \& Reddy BN (1983). Survey of nodulation in gram in Rajastan. International Chickpea News Letter. 9: 24-25.

17. Namvar A \& Sharifi RS (2011). Phonological and morphological response of chickpea to symbiotic and mineral nitrogen fertilization. Zemdirbyste Agri 98(2): 121-130.

18. Feizabady AZ (2013). Effects of crop rotation and residue management on bread wheat. Afr J Plant Sci 7(5): 176-184.

19. Shafi M, Bakht J, Jan MT \& Shah Z (2007). Soil C and N dynamics and maize (Zea mays) yield as affected by cropping systems and residue management in Northwestern Pakistan. Soil Till Res 94: 520-529.

20. Jan MT, Shah P, Hollington PA, Khan MJ \& Sohail Q (2009). Agriculture Research:
Design and Analysis, A monograph. Agric Univ Pesh Pak.

21. Neenu S, Ramesh K, Ramana S, Biswas AK \& Rao AS (2014). Growth and yield of different variaties of chickpea as influenced by the phosphorus nutrition under rainfed conditions on vertisols. Int J Bio-Res Stress Mgt 5(1): 53-57.

22. Saeedullah (2015). Response of chickpea to phosphorus, zinc and their application methods. M.Sc (Hons) Thesis. Agronomy Department, University of Agriculture, Peshawar, Pakistan.

23. Ahmed AG, Ahmed M, Hassanein M \& Zaki NM (2010). Effect of organic and biofertilization on growth and yield of two chickpea cultivars in newly cultivated land. J App Sci Res 6(12): 2000-2009.

24. Dutta D \& Bandyopadhyay P (2009). Performance of chickpea (Cicer arietinum L.) to application of phosphorus and biofertilizer in laterite soil. Arch Agron Soil Sci 55(2): 147-155.

25. Elkoca E, Kantar F \& Sahin F (2007). Influence of nitrogen fixing and phosphorus solubilizing bacteria on the nodulation, plant growth, and yield of chickpea. J Plant Nutr 31(1):157-171.

26. Togay N, Togay Y, Cimrin KM \& Turan M (2008). Effects of Rhizobium inoculation, sulfur and phosphorus applications on yield, yield components and nutrient uptakes in chickpea (Cicer arietinum L.). Afr J Biotech 7(6): 776-782.

27. Yoseph T (2011). Effects of Rhizobium inoculants and $\mathrm{P}$ fertilization on growth, yield and yield components of haricot bean (Phaseolus vulgaris L.) at Umbullo Wacho watershed, Southern Ethiopia, School of plant and Horticultural Sciences, Hawassa University, Hawassa, Ethiopia.

28. Rudresh DL, Shivaprakash \& Prasad RD (2005). Effect of combined application of rhizobium, phosphate solubilizing bacterium and Trichoderma spp. On growth, nutrient uptake and yield of chickpea. Appl Soil Ecol 28: 139-146.

29. Aslam M, Ahmad HK, Himayatullah, Ayaz M, Ahmad E, Sagoo AG, Inayat 
ullah, Hussain A \& Manzoor M (2010). Nodulation, grain yield and grain protein contents as affected by rhizobium inoculation and fertilizer placement in chickpea cultivar BITTLE-98. Sarhad J Agric 26(4): 467-474.

30. Pawar KB, Bendre NJ, Deshmuhk RB \& Perance RR (1998). Field response of chickpea seed inoculation of Rhizobium strains to nodulation and grain yield. $J$ Maharashtra Agric Univ 22: 370-71.

31. El-Hadi EA \& El-Sheikh EAE (1999). Effect of Rhizobium inoculation and nitrogen fertilization on yield and protein contents of six chickpea cultivars in marginal soils under irrigation nutrient cycling in agro ecosystem. 54(1): 57-63.

32. Frossard E, Condron LM, Oberson A, Sinaj S \& Fardeau JC (2000). Processes governing phosphorus availability in temperate soils. J Environ Qual 29: 15-23.

33. Kumar BV \& Sreenivasulu M (2004). Integrated nutrient management. Sci Tech: The Hindu, online Edition of India's National Newspaper, Thursday 12th August, 2004.

34. Fatima Z, Bano A, Sial R \& Aslam M (2008). Response of chickpea to plant growth regulators on nitrogen fixation and yield. Pak J Bot 40(5): 2005-2013.

35. Basir A, Shah Z, Naeem M, Bakht J \& Khan ZH (2008). Effect of phosphorus and farm yard manure on agronomic traits of chickpea (Cicer arietinum L.). Sarhad J Agric 24(4): 567-572.

36. Malhur K, Singh H, Singh VP \& Singh BP (2003). Effect of sources of starter nitrogen and rhizobium inoculation on grain yield and economics of summer mungbean cultivation. Res on Crops 4(2):186-189.

37. Badini SA, Khan M, Baloch SU, Baloch SK, Baloch HN, Bashir W, Badini AR \& Badini MR (2015). Effect of phosphorus levels on growth and yield of chickpea (Cicer aretinum) varieties. J Natural Sci Res 5(3): 169-176.
38. Ali A, Ishtiaq M \& Jan NE (2004). Effect of Rhizobium Leguminosarum inoculum on the growth and yield of different pea cultivars. Sarhad J Agric 19(1): 55-59.

39. Meena KN, Pareek RG \& Jat RS (2001). The effect of phosphorus and biofertilizer on yield and quality of chickpea. Ann Agric Res 22(3): 388-390.

40. Kyei-Boahen S, Slinkard AE \& Walley FL (2002). Evaluation of Rhizobial Inoculation methods for chickpea. J Agron 94: 851-859.

41. Kassa S (2009). Growth, yield and nodulation response of chickpea (Cicer arietinum) varieties to Rhizobia inoculation and phosphorus fertilizer application at Boditi area, Wolayita, Southern Ethiopia, School of Plant and Horticultural Sciences, Hawassa University, Hawassa, Ethiopia.

42. Gidago G, Beyene S \& Worku W (2012). The Response of haricot bean (Phaseolus vulgaris L.) to phosphorus application on Ultisols at Areka, Southern Ethiopia. J Bio Agric Healthcare 1(3): 38-49.

43. Das S, Pareek BL, Kumawat A \& Dhikwal SR (2013). Effect of phosphorus and biofertilizers on productivity of chickpea. Legume Res 36(6): 511-514.

44. Ahmed M \& Badr EA (2009). Effect of bio- and mineral phosphorus fertilizer on the growth, productivity and nutritional value of some chickpea cultivars (Cicer arietinum, L.) in newly cultivated land. Aust J Basic Appl Sci 3(4): 4656-4664.

45. Rokhzadi A \& Toashih V (2011). Nutrient uptake and yield of chickpea (Cicer arietinum L.) inoculated with plant growth-promoting rhizobacteria. Aust $J$ Crop Sci 5(1): 44- 48.

46. Verma JP, Yadav J, Tiwari KN \& Kumar A (2013). Effect of indigenous Mesorhizobium spp. and plant growth promoting rhizobacteria on yields and nutrients uptake of chickpea (Cicer arietinum L.) under sustainable agriculture. Ecol Eng 51: 282-286. 